\title{
Natural resource industries as global value chains: Frontiers, fetishism, labour and the state
}

\author{
Elena Baglioni and Liam Campling \\ School of Business and Management, Queen Mary University of London
}

\begin{abstract}
Despite thirty years of research on global value chains (GVCs), the appropriation of nature in general and natural resource industries in particular remain marginal both theoretically and empirically. There is a parallel ecological deficit in labour process theory and a lack of applied research on natural resource industries. But since historical capitalism is based on the expanding appropriation and transformation of nature by labour, these lacunae must be redressed. Contributing to an emerging body of work in environmental economic geography and the international political economy of the environment, this article theorises GVCs through the lens of the circuit of capital as a tool to unravel some distinctive features of natural resources industries. We propose a framework for the study of natural resource industries as GVCs based on five propositions (a) commodity frontier theory, (b) the fetishism of natural resources, (c) the socio-ecological indeterminacy of the labour process, (d) distance and durability in the production of time, and (e) the contingency of the capitalist state in (re)producing GVCs. While far from exhaustive, we argue that this original synthetic framework provides the crucial bases for a research agenda on GVCs in natural resources.
\end{abstract}

Key words: Natural resource industries, global value chains, global production networks, commodity frontiers, labour process

Acknowledgements: We would like to thank Henry Bernstein, Jairus Banaji, David Demeritt, and three peer reviewers for their constructive and rigorous engagements with earlier drafts of this paper. Earlier versions were presented at the $41^{\text {st }}$ Annual Conference of the Academy of International Business, University of York, April 2014; 'Political Ecology and Development: Resources, Power and Justice', Lancaster University, September 2014; and Research on Organizations 
and the Natural Environment Reading Group, London, June 2016; we are grateful for comments from participants. All errors are ours. 


\section{Introduction}

Natural resource industries are a keystone of the world economy. Such a statement may seem banal except that for over 30 years of global value chain (GVC) analysis these industries and the appropriation of nature more broadly have largely been excluded. ${ }^{1}$ This is surprising because natural resources are materially necessary to the production of both physical and intangible commodities, including services and the products of immaterial labour for which natural resources still provide the means of production (electricity, keyboards), conditions of production (buildings, roads, server hubs) or conditions of reproduction (food, housing, transport). These sectors are the lifeblood of the world economy, the "pressure points" towards which the ever-growing material requirements of all other social practices are conducted and through which they flow' (Benton: 1989, 85). Yet they are 'the beginning of the beginning', but remain taken for granted and under-researched in global value chain (GVC) studies where most analyses start from the transformation of raw materials (Smith 2005).

Whilst renewed interest in the study of production (Selwyn 2012, Starosta 2010) and the constitutive role of labour (e.g. Newsome et al. 2015) represent vital advances in the GVC literature, the persistent neglect of the ecological dimension and dynamics structuring GVC are still preventing a nuanced understanding of the inner workings of global value chains. Largely preoccupied with the sphere of circulation (i.e. exchange relations and the politics of buying and selling), the GVC literature has hitherto neglected the political-economic and socio-ecological dynamics at points of production that come to bear across chains as a whole. This silence is of chief concern here because of the lack of work on how firms appropriate nature and what this means for players downstream the chain (exceptions include Bridge 2008; Havice and Campling 2017). These industries deserve particular attention because 'there is something specific about those sectors in which firms are involved in a direct and immediate way in the appropriation and transformation of nonhuman nature' (Boyd and Prudham 2017, 877).

\footnotetext{
${ }^{1}$ Here we conflate the GVC and global production network (GPN) frameworks. We use 'commodity
} chain' or GVCs to refer to actual production-consumption linkages and value-relations. 
This article seeks to extrapolate some of these specificities to inform a framework for applied research on natural resource industries as global value chains. We highlight the specific character of natural resource industries, i.e. particular forms of industrial organisation rooted in the management and (always partial) control of labour and nature. We incorporate in these industries extractives and agriculture, including fisheries and forestry, which straddle the two. ${ }^{2}$ We suggest a framework for the analysis of these industries that seeks to operationalize the abstract relation between capital and nature (Castree 2003, Smith 2010, Burkett 2014, Moore 2016) in more concrete ways, but that allows for multi-sited and potentially comparative insights beyond local-scale case studies. $^{3}$ This meso-level analysis contributes to both the GVC and environmental economic geography literatures in at least three ways.

First, we combine the focus of GVC analysis on inter-firm power relations ('chain governance') with the more historical, socio-ecological emphasis of commodity frontier theory (Moore 2015) to propose a complex, multi-layered understanding of the organisation and relations of natural resource industries. By emphasising the unity of capitalist production and exchange, we consider power relations both between and within firms, building from critical GVC/ GPN studies (e.g. Bair and Werner 2011), including recent engagement with labour process theory (Newsome et al. 2015). ${ }^{4}$ Commodity frontier theory situates the historical development and expansion of capitalist production through nature, emphasising

\footnotetext{
${ }^{2}$ We emphasise a blurred distinction between the 'formal' and 'real subsumption of nature', both always relationally linked to, and mediated by, the labour process in contextual and contingent ways (Boyd et al. 2001; Boyd and Prudham 2017). Rather than a binary understanding of different natures (e.g. between biological and nonbiological industries), this lens highlights the inherent tension between capital's control of nature and its limits. We exclude the 'real subsumption' of nature such as genetically modified organisms, biotechnology, etc. (Boyd et al. 2001), and focus on 'received nature', that which, following Boyd et al.'s formula, is only 'formally subsumed'. Indeed, in its proper sense, "there is little evidence of successful efforts at such real subsumption of nature to date'; instead value is derived from claims to intellectual property over the application of knowledge to agriculture (Birch and Tyfield 2013: 315).

${ }^{3}$ In this way, the meso-level approach adapted here draws parallels with Bridge and Jonas' notion of critical industrial ecology: 'an institutional political economy that is attentive to the socially constructed yet biophysical character of nature [which] offers a compelling framework for analysing and explaining recent shifts in the institutions of resource production and consumption (2002: 764-5).

${ }^{4}$ We use firms as shorthand for a diversity of economic agents, from petty-commodity producers to giant multinational corporations with truly global reach. As emphasized by Henderson et al. (2002), many other agents make-up and influence the working of GVCs, including the state, as we discuss below.
} 
the diversity of geographies, while simultaneously recognising the 'gravitational pull' of the capital-relation (Moore 2011; Shaikh 2016). Overall we emphasise that the challenges and opportunities encountered in appropriating and transforming nature spur the continuous geographical, organisational, and technological change intrinsic to GVCs. This highlights how the appropriation of nature and its transformation into natural resources represent a fundamental but hitherto unacknowledged 'causal driver' (Yeung and Coe 2015) prompting the constant (re)configuration of commodity chains.

Second, if the appropriation and transformation of nature drives the emergence and continuous evolution of GVCs, the reverse perspective emphasises that GVCs represent contemporary capitalism's ever-shifting ways of organising and pursuing the appropriation and transformation of nature. Lead multinational corporations are dominant entities in and administrators of GVCs, which are in turn the leading organisational form of international production and trade (Nolan et al. 2008; UNCTAD 2013). In this sense and to paraphrase Moore (2015) global value chains are a way of organising nature. This highlights the relevance of critical GVC/GPN research for environmental economic geography. Critical GVC research already emphasises relations over entities, and dialectical over linear relations (Bair 2009; Palpacuer 2008; Pickles and Smith 2016; Taylor 2008). Both analytical starting points are crucial to understanding historically how capitalism establishes qualitatively (and consequently quantitatively) different relationships with and through nature, based on its valorisation through labour. GVC analysis has the unique ability to map and dissect an industry through its multiple and simultaneous constitutive relations between capital and labour, between capitals, between capital, labour and states and other institutions (Cumbers et al. 2008; Selwyn 2012; Smith 2015), and we would add, between these and nature.

Third, by proposing a research agenda of natural resource industries as GVCs we contribute to redress the 'relative neglect of [the] bigger picture' (Clapp and Helleiner 2012: 490; see also Bakker 2012) ${ }^{5}$ affecting both environmental economic geography and the international political economy of the environment. However, this is often done (a) at a high level of theoretical abstraction or (b) by

\footnotetext{
${ }^{5}$ Prominent exceptions are cited through this article.
} 
identifying individual or sets of empirical phenomena but without theorising the linkages among them beyond loose criticism of the dangers of 'corporate power'. Newell (2011) argues that much of the academic understanding of capitalism and ecology has been weakened as a result of diverse disciplinary biases, the general hostility to historical materialism in the Academy, and a reading of capitalism 'as given'. Similarly, Clapp and Helleiner (2012) point out that the interface between political economy and the environment has been approached mainly through causal 'arrows' emphasising how the global political economy affects the environment, or (more rarely) how scarcity of resources and the finite capacity of the earth largely impacts on the former. The dialectical (hence historical) relation between these phenomena has gone missing.

In what follows we seek to equip critical GVC analysis with the tools to understand dynamic forms of industrial organisation rooted in the appropriation of nature and exploitation of labour. In section two we integrate our concern with capitalist production with the emphasis of GVC analysis on relations between firms through the theoretical prism of the circuit of capital. Having suggested a theoretical basis for the unity of production and exchange, we move in section three to devise an analytical framework of five interconnected propositions that develop the study of natural resources as GVCs: (a) commodity frontier theory, (b) the fetishism of natural resources, (c) the socio-ecological indeterminacy of the labour process, (d) distance and durability in the production of time, and (e) the contingency of the capitalist state in (re)producing GVCs. ${ }^{6}$ The propositions are illustrated with examples from natural resource industries. We do not assume that this entire set of propositions could be programmatically 'applied' to any single research project, but we do argue that to achieve an understanding of one aspect it must be set in relation to the others, even if only at a general level.

\section{Global value chains, the circuit of capital and nature}

\footnotetext{
${ }^{6}$ There are, of course, plenty of others (e.g. financialisation, standards, etc.), but we could not do them analytical justice in the space of a single article. Instead, our intention here is to centre on explanation and to avoid a chaotic whole. We do not claim to account for everything.
} 
As is well known, the GVC literature has been characterised by an enduring bias towards relations of exchange rather than relations of production. We do not rehearse the well-known genealogy of the development of discrete frameworks in 'commodity studies' (Bernstein and Campling 2006). As Bair (2009) and Ponte and Sturgeon (2014) make clear, applied GVC and GPN research tends to be very similar, despite proponents' claims to distinctiveness. Recent theoretical work within GVC and GPN '2.0' frameworks suggest greater precision in typologies of chain governance to enable comparison and generalisation across cases and better inform policymakers (Ponte and Sturgeon 2014; Yeung and Coe 2015). This aspect of the GVC project is typified by Gibbon et al. (2008) as a theory of interfirm linkages. But to take nature seriously we need to recognise the complementarity between the spheres of circulation and production because the ability of lead firms to govern GVCs cannot be disjoined from the appropriation of nature, strategies to control the labour process, and firms' associated ability to capture surplus value. The sphere of circulation greatly influences the competitive vertical and horizontal conditions within which firms operate, which have profound implications for the sphere of production. To elaborate, to survive the dynamics of competitive accumulation a particular firm may need to intensify or extend the labour process or speed-up movements of money or commodity capital to enhance turnover time (often pushing the intensification or extensification of the labour process elsewhere). However, the sphere of production cannot be explained by relations among firms - this black box needs to be opened and the appropriation of nature and exploitation of labour examined.

Drawing from Fine and Leopold's (1993) 'systems of provision' and Pickles and Smith's (2016) 'articulations of capital', we suggest that the development of any given commodity chain and the ever-growing complexity of its division of labour, reflects the historical evolution and dialectical relationship between relations of production and exchange that mutually constitute the circuit of capital. For Marx, this starts when the capitalist goes to the market as a buyer to exchange money for labour power and means of production. Then, the capitalist consumes the labour power and means of production producing a commodity which has a value greater than that spent on the initial market purchase. Finally, the capitalist reappears on the market as a seller of the commodity produced in 
exchange for money. From this point of view relations of production and of exchange are simultaneously a pre-condition and 'obstacle' to one another. If commodities are not sold on the market profit is neither realized nor reinvested in producing further commodities. Likewise, if means of production and/or labour power are not available production cannot take place. If, finally, production falters there are no commodities to be sold on the market. In sum, interruptions can occur both at the point of production and at the point of exchange: hence capital's imperative to ensure that production and exchange occur smoothly and rapidly, for as swiftly as the circuit is completed the sooner profit is realized and the process can start again.

In thinking about commodity chains, the circuit of capital can be identified at the level of individual enterprises and at the generalised level of all processes and relations of production and exchange (i.e. the totality of enterprises). This was summarised by Marx (1993) in Volume II of Capital:

Every individual capital is ... on the one hand ... an agent of the general circulation of commodities, in which it either functions or lies concatenated as money or as a commodity, thus forming a link in the general chain of metamorphoses taking place in the world of commodities. On the other hand it describes within the general circulation its own independent circuit in which the sphere of production forms a transitional stage and in which this capital returns to its starting-point in the same form in which it left that point. Within its own circuit, which includes its real metamorphosis in the process of production, it changes at the same time the magnitude of its value. It returns not simply as money-value, but as augmented, increased money-value.

Commodity chains are in turn part of the total production and circulation of commodities - and indeed at a phenomenal level they constantly leak into each other (e.g. through the provisions of raw material and intermediate commodities, labour, services, credit, etc). Individually, commodity chains represent the 'biography of commodities, which move between various sites of production, exchange and consumption as they flow around and beyond the circuits of capital' 
(Hudson 2008: 425). ${ }^{7}$ These are riddled with power relations both within and between firms as struggles over the production and distribution of value. At the firm-level, capitalist production includes the labour process and the extraction of surplus value from it, as well as the realisation of that value through exchange. Although happening at the firm level, production is never a self-contained process: what happens inside the 'black box' of the firm is shaped by the 'outside' world it is territorially and socially embedded (Henderson et al. 2002; Taylor 2008). Thus, power relations within the firm develop dialectically with those local and wider forces that affect the production and distribution of value between capital and labour, including the conditions of labour reproduction. As such production always exists in continuity with power relations (e.g. gender and race), processes and institutions 'external' to firms. Likewise, relations of exchange between firms are also riddled with power struggles over the distribution of the value produced. This is the theatre of chain governance. But it does not necessarily prioritise 'lead' firms. The focus on exchange between firms is insightful because it is a site of contestation where rules affecting production are set that are designed to capture value or pass on risks and costs. These rules can take the form of contracts, standards and/or other forms of (in)direct control of production that span the boundaries of the firm.

Thinking through the circuit/s of capital is particularly relevant to the study of natural resource industries where capital confronts and realises the direct transformation of nature into value. At a concrete level, this transformation meets challenges and opportunities that can obstruct, lengthen or speed-up the circuit of capital at different points. At a more abstract level, this transformation sets a crucial tension between capital and nature because not all the nature consumed in production is reflected in the value of the commodity produced

\footnotetext{
${ }^{7}$ Not all value chains are truly global. For example, multinational corporations are often regional in industrial organisation (Rugman and Girod 2003); value chains in natural resources often reflect regional histories of geo-political spheres of influence (e.g. Campling and Colas forthcoming); and, beyond questions of scale, types of space matter such as topological features, including volumetric ones (Bridge 2013). Nonetheless, the term 'global' helps to highlight the interconnectedness of labour, inputs, and market dynamics connected by the circuit of capital in its totality; even if a particular value chain is not global in its immediate boundaries, most will be so in relation to other GVCs.
} 
(Henderson 1999). This inconsistency is carried out along the circuit of capital and eventually magnified across 'the world of commodities'.

Environmental economic geography has emphasized that 'natural conditions' invariably pose opportunities and constraints to capitalist accumulation (e.g. Bakker and Bridge 2006). Geological, biophysical, and biological processes shape, and are shaped by, the transformation of matter and living organisms into raw materials and finished products (and everything in between). Whereas some natural resource industries like oil, gas and mineral extraction face the challenge of more pervasive geological and biophysical conditions, others like agriculture, fishing and forestry can achieve a more extensive control of the biological process. But even in these sectors capitalist subsumption of nature is never fully achieved: 'natural conditions' always shape and fetter the circuit of capital. For example, the life cycles of plants and animals can be accelerated but never annihilated, hence idle-time cannot be totally eliminated. In other words, 'No matter how far down the current commodification of life and the associated remaking of biological reality goes, from salmon crossed with tomatoes to the spectre of the new eugenics, capitalism will always rely to some extent on non-produced inputs' (Prudham 2005: 7). In this sense, whilst capitalism is constantly engaged in the social production of nature (Smith, 2010), it simultaneously and necessarily relies on non-produced nature. This need lies at the heart of the historical evolution and transformation of nature into natural resources.

Value theory points to a crucial tension at the point of production in terms of the 'measure' of labour and nature. Within the labour process, nature represents a necessary use-value (i.e. matter to be transformed by labour power and labouring bodies themselves) that labour transforms into a commodity (e.g. a raw material), but the value of which is determined exclusively by socially necessary labour time. However, as Marx puts it in the opening pages of the Critique of the Gotha Programme and which is to be found in all children's primers':

Labour is not the source of all wealth. Nature is just as much the source of use values (and it is surely of such that material wealth consists!) as labour, which itself is only the manifestation of a force 
of nature, human labour power! (Marx 2008: 18, emphasis in original).

Paul Burkett elaborates usefully on the crucial point on what is and is not 'valued' by capital: 'quantitatively, capitalism only ascribes value to nature insofar as its appropriation requires commodity-producing labour, even though nature's contribution to production - and to human life more generally - is not materially reducible to this labor of appropriation' (2014: 80). In general, nature's indirect contribution to value establishes a contradictory relation where natural conditions are in an inverse relation to value. That is, the greater the 'free gift' (of matter and socio-natural conditions ${ }^{8}$ ), the less necessary labour time is required and hence less value is produced (i.e. commodities are cheapened). ${ }^{9}$ Marx uses 'free gift' here in the sense of matter and/or socio-natural conditions that enhance labour productivity without the matter or conditions being directly paid for by capital. (For the quasi-monopoly owner of portions of the earth, this relation produces a redistributive claim on surplus value in the form of ground-rent (Marx 1981).) In Jason Moore's (2015) terms, these are zones of 'high ecological surplus' (assuming they are conducive to human appropriation and capitalist transformation). As this high ecological surplus is progressively exhausted in the production of cheap raw material, the labour/time and technology needs increase thereby affecting the different metamorphoses of capital along its circuit/s: technical and organisational technologies (including in labour markets and within the labour process) develop to unhamper the circuit of capital until capitalists find new, cheaper commodity frontiers.

In the next section we advance an operationalizable research agenda to examine and compare the dynamics of natural resource industries as global value chains through the prism of the circuit/s of capital and the power relations embedded in them. This agenda simultaneously seeks to make space for the historical contingencies and geographical specificities of the constitutive

\footnotetext{
${ }^{8}$ Burkett and Moore each include here categories of collective labour, reproductive labour, and free knowledge. Importantly, they emphasise that 'free' appropriation does not imply limitlessness.

${ }^{9}$ Burkett (2015) emphasizes this dynamic but does not frame it through an inverse relationship. This logic is also central to Moore (2015).
} 
interactions among capital, labour, nature and states; no outcome is automatic, even though it might appear that way.

\section{Propositions to analyse natural resources industries as GVCs}

We suggest five propositions for the initial - but inevitably incomplete unravelling of the complexity of natural resource industries as GVCs. They are each deeply inter-related but, for analytical purposes, are explored separately. Our first proposition historicises natural resource industries as commodity frontiers (proposition a), building on our theorisation of the centrality of production to GVCs in the prior section. We then move to the materiality of 'natural' resources and their double fetishism as concealing labour exploitation and as a sociopolitical construction (proposition b). This leads us to the transformation of nature into natural resources through the labour process and its social and ecological indeterminacy (proposition c). This transformation means that capital is immediately confronted with the dual problem of distance and durability (proposition d), which firms seek to address with innovations to produce time (e.g. the preservation of food, logistics) to complete circuits. Finally, states try to stabilise this system - introducing property rights at national and international scales and ensuring the security of linkages in GVCs (e.g. geo-politics) - but they do so in immanently contingent ways (proposition e).

\section{Proposition a: natural resource GVCs can only be properly understood in historical and geographical motion.}

Commodity frontier theory is the keystone in our set of propositions and combined with the insights of critical GVC studies puts our framework in historical and geographical motion. We seek to distil aspects of Jason Moore's work to show how it can be operationalised alongside other theoretically compatible concerns and, in turn, itself potentially advanced in new directions - including by more explicitly incorporating the state, which we do with proposition e.

Historical capitalism is shown by Moore to be (necessarily) reproduced through new commodity frontiers which are based upon the appropriation of 
nature through the labour process. ${ }^{10}$ This does not specify 'a "social" process and its "environmental" consequences, but rather a dialectic of two bundles of human and extrahuman nature' (Moore 2012: 2). Firms are driven to produce new commodity frontiers because of the enhanced possibilities for accumulation when entering zones of minimal (or zero) prior appropriation of nature. And this is one of Moore's crucial points: appropriation in new commodity frontiers is faster than existing zones of commodification allowing for a relative competitive enhancement of the productivity of labour. This 'commodity-widening strategy' based on extensive development ${ }^{11}$ offers the possibility of the appropriation of a high ecological surplus by firms (Moore 2010: 219). Where there has been human resistance to this strategy, it has historically been of limited effect in slowing this process in the face of capitalist states and their militaries (public or private). ${ }^{12}$

With appropriation over time, the initially high ecological surplus deteriorates into 'mature' frontier conditions. The typical responses by capital to these conditions are to search for a new frontier or intensify the appropriation in an existing frontier through enhanced 'capitalization and socio-technical innovation' (Moore 2012: 3). ${ }^{13}$ This 'commodity-deepening' strategy generates a new 'frontier' based on intensive development. This is why commodity frontiers are historically zones of innovation, such as cutting edge technology developed to intensify extraction and extend transportation of raw materials (see proposition d). Ecological surpluses are revealed by the combination of science, technology and capital at particular historical moments (Bowker 1987) - they are not just 'there'. In this way, firms dependent upon the appropriation of natural resources seek to continuously expand into new commodity frontiers, whether in terms of geographical extent or industrial intensity. This process is of course contingent

\footnotetext{
${ }^{10}$ Moore's use of 'frontier' explicitly does not suggest a place of 'discovery', but that frontiers reflect the perspective of capital seeking to appropriate nature.

${ }^{11}$ Moore's framework has some parallel with Ben Fine's distinction between 'extensive and intensive development' or 'the extension of existing methods of production on to new lands and the intensive application of capital to land already in use' $(1994,283)$, which in turn is influenced by Marx's analysis in Capital Volume III (1981) of differential rent I and II.

${ }^{12} \mathrm{An}$ important example of a limit to commodity widening has been the blocking of seabed mining in oceanic areas beyond national jurisdiction ('the Area'), as administered by the International Seabed Authority. There are however, contemporary moves by capital in concert with Pacific Island countries to expand into this deepsea frontier (Zalik 2015).

${ }^{13}$ Not all new frontiers are opened because others are 'exhausted', in the sense of the decline of relative ecological surplus (and the promise of super-profit). Frontiers may be opened for other reasons including inter-capitalist competition as mediated by geo-politics (see Podobnik 2003).
} 
upon access and use (e.g. property relations), which we discuss in relation to the state and geo-politics below. With this in mind, it is also worth highlighting the amount of analytical weight that the category 'appropriation' carries. ${ }^{14}$ We think it has a double sense: first, as the appropriation of the work-energy flows of (non)human nature, which according to Paul Burkett and Jason Moore is not paid for; and second, as the portion of surplus value (ground-rent) that is captured by way of the property relations that are associated with access to nature and predicated upon the future productive labour applied to that land/location, which introduces the class relation of modern landed property.

Research that seeks to develop Moore's framework includes Ross (2014) on how the decline of European tin production drove colonial expansion into parts of Southeast Asia producing new frontiers, not least as raw material for that ultimate industrial capitalist source of working class and military sustenance canned food. Colonial ideologies of race, waste and industrial efficiency animated the formation and reproduction of the tin commodity chains. Over time, commodity deepening strategies reconfigured definitions of mineral 'deposits' when initial ecological surpluses were depleted, enhancing throughput and productivity. But as ever, environmental costs were 'externalised' and 'defaced mining landscapes were situated at one end of a long chain linking the kitchens and factories of the industrialized world to the forests of Southeast Asia' (Ross 2014: 12). The formation of commodity chains in natural resources is then an articulation of capital with particular regions where 'frontier' conditions are present, which crucially incorporates the exploitation of labour (proposition c).

Commodity frontier theory insists that capitalism 'does not have an ecological regime. It is an ecological regime' (Moore 2010b: 392, author's italics). Commodity frontiers articulate particular regions with world-market dynamics, extending the market discipline of circuits of capital and the reach of commodity chains, and new and differentiated types of industrial organisation are formed. These new geographies, new techniques, new organisation, and new class relations are not exogenous to, but rather constitutive of, successive commodity

\footnotetext{
14 This is in contrast to our use of exploitation as an analytical category exclusively in relation to the extraction of surplus value from labour (e.g. the rate of exploitation of unpaid labour). We do not use it in the descriptive sense of, for example, migrant workers being more exploited more than non-migrant workers; and we do not talk about the 'exploitation' of nature.
} 
frontiers (Campling 2012; Marley 2015). In seeking to activate commodity frontier theory to think through the analysis of global value chains, we suggest the following questions: How do firms appropriate nature through production? How does the availability of cheap nature (and labour) effect inter-firm relations? How do power relations between and within firms (e.g. chain governance) change according to the extensive or intensive development of commodity frontiers? Put, more generally, do commodity frontiers shape GVCs in particular ways? What is the role of the state in general and of (historical) imperialism in particular in the widening of commodity frontiers (proposition e), including the protection of transportation routes? What types of innovations to preserve and move raw materials around the world do commodity frontiers demand (proposition d)? For example, after a region's initially high ecological surplus is exhausted, what are the implications for the completion of competitive circuits of capital and of the commodity?

\section{Proposition b: Natural resource industries are masked by a double fetishism which shapes their development as GVCs}

As with any other commodity form, natural resources need to be deconstructed. The fetishism attached to natural resources is twofold. First, like all commodities, natural resources necessarily conceal the social relations of exploitation out of which they are produced (proposition c). These can neither be seen through the materiality and usefulness of the commodity, nor through the additional meanings that advertisers confer on them. In deconstructing gold, Hartwick (1998: 430) shows how corporate producers and advertisers powerfully and successfully charge gold with strong meanings of love, commitment, and economic power, omitting how in South Africa miners work in cramped tunnels, deep in water and breathing dirt-laden air, and live in wired camps where a 'miner's every action is under constant surveillance'. The first analytical step then, is to recognise is that natural resources are a socio-ecological product: they are the outcome of a social relation of production, and one which is based on the exploitation of labour, which revolves around the appropriation of unpaid nature (the 'hidden abode' of production). 
Second, natural resources are also a socio-political construct. Paradoxically, 'natural resources are not, in fact, "naturally" resources' (Dicken 2010: 244). Particular matter occurring in nature becomes a resource exclusively through particular human interactions, which change in time and space. Through human utilitarian interaction 'plants that are valued become crops; the species that compete with them are reclassified as weeds, and the insects that ingest them are classified as pests. Thus, trees that are valued become timber while species that compete with them become 'thrash' trees or underbush' (Scott 1995, 84). In this sense resources are not; they become (Zimmerman 1951). Thus, matter becomes a natural resource in concert with the social priorities of any mode of production and commodity sector, the socio-cultural context (e.g. effective demand, appropriate technology) and different priorities in political choice (e.g. ensuring property rights over access and use). ${ }^{15}$ Natural resources have then a dual quality 'part physical entity and part social category' (Bridge 2009: 1219) that shape one another dialectically.

Following from this, the socio-political construction of natural resources is therefore inherently relational. Just as humans 'determine' natural resources by 'discovering' and 'inventing' new use and exchange values, appropriating and commodifying nature, so do natural resources shape and determine the limits and potential of the production process (Castree 2003). Indeed, the tension between the social and physical attributes of natural resources further shows that natural resources are simultaneously dynamic and static. On the one hand, their sociopolitical construction as resources is inherently dynamic: it is made and unmade according to different times and place. However, some aspects of their materiality confer on them static properties. Whether non-renewable or renewable-butexhaustible they compel the production process to conform to their geo-physical/ biological characteristics. Compare, for example, relational environmental conditions of extraction in terms of mining and the geophysical (Capps 2012), soil and climate (Mann and Dickinson 1978), and fish and biology - i.e. fish move but within spatial-biological limits (e.g. Campling 2012). Hence appropriation requires specific labour processes, the development and application of techniques

\footnotetext{
15 On these themes, see the classic discussion in Harvey (1974).
} 
and technologies attempting to maximise labour productivity and minimise labour organisation and resistance (proposition c), overcome problems of distance and durability (proposition d), and the intermediation of states to regulate access and transport (proposition e).

Timothy Mitchell's (2011) counterpoint of the social organisation of production of coal and oil is instructive here. The industrial extraction and transformation of coal required particularly labour-intensive process that is hidden beneath the sub-soil, away from the prying eyes of managers, to produce a heavy and bulky raw material whose transportation requires the use of 'national' railways, docks and ports that could also be sabotaged by organised labour. In contrast, the 'fluidity' and relative 'lightness' of oil is based on drilling above ground and transportation via pipelines and transoceanic shipping, together significantly reducing the number of critical choke points across the oil production network. Kaup (2014) makes a similar point when comparing mining and drilling in Bolivia. The low technological intensity of the mining sector (principally tin, zinc, antimony, tungsten and gold) has provided sustained, albeit dangerous, employment, while the high technological intensity of hydrocarbons (oil and gas) generated booms of employment in periods of exploration (to find, drill and build transport pipelines) followed by busts of unemployment during periods of extraction (when only skilled labour is required to operate technology and infrastructure). The fact that some minerals require very little extraction technology takes extreme consequences in the Democratic Republic of Congo. As Nest (2011) shows, here the physical and chemical properties of high-value minerals like coltan, gold, tungsten, and diamonds have allowed for mining in the absence of secure property rights and a strong state. The high market price of these minerals and their physical amenability both to artisanal production (i.e. they are found in relatively high density and are often accessible via deposits that are at the surface or proximate to it) and to transportation and smuggling (i.e. high levels of chemical inertness mean they require little or no post-extraction treatment and are high value but small volume and low bulk), have made these 'industries' particularly suitable to finance war.

With these points in mind, when looking at the role of natural resource industries in GVCs we suggest that it would be fruitful to ask: how do the material 
properties of natural resources shape the capital-labour relationship (proposition c) and the overall circuit of capital? And how do these properties influence the mediating roles of technology (proposition d) and of the state (proposition e)? More broadly, in what ways (if at all) do the dynamic/static properties of natural resources twist capitalist development in new directions when appropriating nature across new borders and through new socio-economic metabolisms? As we have seen, this longitudinal perspective is at the core of our perspective in thinking about capitalist natures as 'commodity frontiers' (proposition a).

\section{Proposition c: The labour process in natural resource industries is both socially and ecologically indeterminate, which dynamically shapes global value chains}

A central assumption of our approach is that a resource is not a resource without labour. It is labour, regulated and controlled through the labour process that transforms nature into 'natural resources'. Hence, the labour process represents the very interface between nature and its commodification, the actual realisation of 'capitalism in nature' (Moore 2015). Yet, there is a well-known 'labour deficit' in GVC studies (Coe et al.2008; Rainnie et al 2011), and little awareness of a 'nature deficit' in the labour process literature. ${ }^{16}$

Despite theorising the capitalist labour process as historically specific social relations of production through nature, nature has not been under the spotlight of labour process theory (Brighton Group, 1977). In his original formulation Marx emphasises that the labour process is a metabolic relation between people and nature where both people and nature shape one another (Marx 1992). Yet, the dialectical relationship between people and nature that constantly revolutionises the labour process has been overlooked. We propose retrieving the role of nature in shaping the labour process in natural resource industries by building on the notion of indeterminacy central to labour process theory (Taylor et al. 2015).

\footnotetext{
16 Labour process theory's silence on nature is apparent from McGrath-Champ et al. (2010), Newsome et al. (2015) and Thompson and Smith (2010). An appendix in the latter details the most influential texts in LPT, none of which addresses the 'problem' of nature theoretically or research in natural resource industries empirically.
} 
First, as in all other industries, the production process is indeterminate because it is mediated by unequal social relations of production (Smith 2006). ${ }^{17}$ The lack of total control over labour is expressed in antagonistic relationships between employers and employees. Despite employer organisation, supervision and managerial strategies to control labour, the organisation of production remains unequal and conflict-ridden, whether the conflict is overtly manifest or not. Therefore, the indeterminacy of labour is a fundamental source of social indeterminacy affecting the capitalist labour process. Second, unlike other industries, natural resource industries face the problem of directly confronting nature, the appropriation of which sets obstacles and challenges that are superseded only partially or momentarily (Burkett 2013). Hence, as with labour, the domination of nature is 'a process never entirely accomplished' (Smith 1996, 48). The ways in which this second type of ecological indeterminacy may affect the labour process, the organisation of production, and inter-firm dynamics in GVCs, deserve proper investigation.

Agrarian political economy has devoted particular attention to the constraints posed by nature to capitalist agriculture. The most evident include seasonality and weather, the constraints that growth cycles of plants and animals pose to the circuit of capital, the spatial extension of production activities, and the cost and difficulty of labour supervision and control in the fields compared to factories. ${ }^{18}$ From this perspective, the history of capitalist agriculture can be read as a permanent struggle to standardise, control, and simplify nature and the uncertainties of natural environments through continuous socio-technological innovation (proposition d). Weis (2007) and Moore (2015) argue that this struggle is however never-ending: the sweeping simplification of environments intensifies the biological and physical challenges inherent in farming, generating and exacerbating a broad spectrum of bio-physical instabilities, hence establishing new problems at a greater scale.

\footnotetext{
17 To this Chris Smith (2006) adds a further level of indeterminacy of labour deriving from workers' (limited) freedom/power to change job.

18The tradition of considering how nature affects capitalist accumulation, and consequently the organization of the labour process, dates back to Kautsky (1900) and was subsequently revived by the seminal work of Mann and Dickinson (1978). For a brief summary of the most manifest ways in which nature shapes capitalist accumulation in agriculture see Bernstein (2010).
} 
Within forestry some of these challenges escalate. According to Prudham's work in the forests of Oregon, the lengthy process of tree growth and the ensuing gap between production time and labour time 'dwarfs the seasonal problem in agriculture' (2005: 32). Labour control is greatly challenged by the fact that 'workers are typically deployed over a wide area and are constantly on the move' (2005: 31). Other elements challenging the control of labour include the uneven topography of the forests, types and size of trees, and the risks and logistics of logging. As forests impede the regularity, predictability, and labour control of factory production the labour process is organised along flexible and piece-work contracts that shift many production risks to workers.

Similarly, Burawoy has argued that the distinctive features of mining organisation originate in the inescapable environmental uncertainty of the underground ore bodies from which minerals are extracted' (1982: 206). Geological and physical barriers have shaped the labour process in natural resource industries in essential, but often quite different, ways. Systems of labour control in mining reproduce and reinforce the isolation of underground activities as a 'world apart': from the social and cultural segregation of miners from 'surface workers' in upstate New York (Gouldner 1964), to the spatially and racially confined mining camps of South African (Bezuidenhout and Buhlungu 2011).

Therefore, ecological indeterminacy can greatly affect the social indeterminacy of the labour process and shape the antagonism between employers and employees. In some mines, the inherent risks of underground activities and different dimensions of isolation (spatial, cultural, racial) provided new bases for forms of labour resistance and collective organisation (Bezuidenhout and Buhlungu 2011). In Brazilian export-grape production, market pressures have transformed farming in a mechanised and synchronised, industrylike, activity. Farmers' ability to transform nature 'just in time' provided large segments of their workers with effective powers of disruption, which were used to negotiate improvements in working conditions (Selwyn 2007).

Once organised within complex GVCs, the ecological and social indeterminacy of labour process can acquire a strong bullwhip effect, as manifested by disruptions, environmental or health crises, including recurrent 
food scares (Freidberg 2004). This is because production and exchange are necessarily linked: the way the labour process shapes the firm-level circuit of capital (as momentarily suspending and shaping it) affects the whole commodity chain. Therefore, the question of how capitalist production works through and against labour and nature remains crucial to GVC analysis of natural resource industries: to what extent does nature time slow down and complicate inter-firm relations? How do employers discount the increased risks of producing as appropriating nature (proposition a)? How do ecological and social indeterminacies of producing in natural resource industries shape inter-firm relations in the wider GVC? And what are the possibilities for labour agency under socially and ecologically indeterminate relations and conditions of production? Do natural resource industries offer enhanced possibilities for labour agency (e.g. relative territorial embeddedness, the bullwhip effect)?

\section{Proposition d: In natural resource industries capital seeks to shorten its circuit while overcoming the problems of distance and durability}

To varying degrees, capitalist interests trying to organise commodity chains in natural resources are faced with the dual problematic of 'distance and durability' (Friedmann 1992) that poses a number of challenges to the circuit of capital. Despite the clear importance of 'how nature informs food distribution' research is 'relatively scarce' (Freidberg 2001: 361). Firms attempt to overcome (and profit from) the tension between the organic and the synthetic (e.g. Kloppenburg 2004; Weis 2007), and those engaged directly in the transformation of organic matter face the risk of it deteriorating before exchange (and eventual final sale) is realized. But 'durability' is not limited to organic matter - iron ore, for example, must be protected post-extraction to maintain quality (Fisher 2016) - and thus should be seen as a continuum rather than as a binary of organic/inorganic. Nonetheless, to mitigate the risk of waste of biological raw materials, a range of business strategies and technological innovations have been developed to (partially) synthesise the organic so as to maximise the potential for accumulation (e.g. preserved food; see Fine and Leopold 1993). Among these is logistics, which 
both elongates GVCs and facilitates the opening of new commodity frontiers. At the same time logistics industries are themselves materially intensive - fuel, steel, pollution - and thus contribute to the reproduction of socio-ecological contradictions.

The abatement of transport barriers through successive organisational and technological breakthroughs has been the essential vehicle for capitalist development since its very inception (Fields 2004). Transport and communications revolutions (logistics) reshape social relations of production between capital and labour and between firms - by enabling production under new terms. By shrinking space and time, they allow for the overcoming of distance: by accelerating the circuit of capital they set new rules of the competitive game. The use value of logistics is to move things from place to place in order to realise exchange value (it completes a circuit) while producing surplus value through the labour process in ports, on boats and in distribution centres (Marx 1993; Newsome 2010). In short, advances in logistics - and, to repeat, they can be organisational just as much as they can be technological - both save time and produce time. Conversely, by shortening the life-cycles of plants and animals and lengthening the life-cycles of commodities, or outrightly substituting them, technology mitigates the problem of durability: providing more time for the circuit of capital to be concluded or speeding the process up. ${ }^{19}$ Thus, distance and durability can be understood as material challenges that nature poses on its commodification.

The history of the capitalist food economy is largely a story of the drive to make the organic more synthetic. A prominent example is the canning of food, which was sparked by the combination of the exigencies of war and the competitive demands of the circuits of capital and commodity. Due to the cuttingoff of cane sugar supply to France (then widely used for the preservation of food) in the Napoleonic wars and the objective of reducing reliance on imported food, the French state offered a substantial grant for new methods for food preservation (Warne 1988). In the case of capture fisheries, canning allows large catches to be

\footnotetext{
${ }^{19}$ For an analysis of the increasing discrepancy between social and biological time since the industrial revolution see Adam (1998).
} 
preserved - delaying decay - during high fishing seasons without the significant adulteration of flavour and texture that came with earlier methods of preservation such as salting, smoking or drying (Shephard 2000). Enhanced quality and increased durability expanded the geography of markets. For example, canned sardines were exported from France to supply miners in the mid-nineteenth century gold-rushes in California and Australia (Dias and Guillotreau 2005), while salmon canneries in British Columbia meant that 'a proletariat was created in order to feed the British working classes' (Muszynski 1996: 13). ${ }^{20}$ And while the question of durability is of greatest concern for raw material based on biological matter, stressing the continuum noted earlier, even iron ore must be protected from rain before being processed both to maintain quality and to comply with social regulation on Safety of Life at Sea which limits the moisture content of ore on dry bulk carriers (Fisher 2016).

With these examples in mind, we suggest several potentially fruitful avenues for GVC analyses of natural resource industries. While speed-up in turnaround time drives demands on logistics by all industries, does the heightened sensitivity of bio-physical matter to the operational problems of time and distance make natural resource industries especially innovative in this sphere? What is the relationship between the historical formation of commodity chains in natural resources and the aim of overcoming distance and durability? Or more specifically, to what extent do commodity frontiers produce or are produced by innovations in logistics? And is the governance of natural resource commodity chains more or less influenced by firms leading the logistics nodes of the chain?

\section{Proposition e: The state (re)produces commodity chains and frontiers in natural resources in always-contingent ways}

GVC studies that invoke the state often do so simply as a provider of policy infrastructure or as a narrow political context. A preliminary step in theorising in GVC analysis is that 'the state is clearly not a unitary entity, but a constellation of functions and capacities' (Neilson et al. 2014: 3). Arguably though, whereas state

\footnotetext{
${ }^{20}$ In turn, the materials necessary to produce canned food sparked new commodity frontiers, as noted earlier with the example of tin (Ross 2014).
} 
effects vary dramatically in place and time, some of these are much less erratic. Most of all one cannot easily dismiss the centrality of states in the overall reproduction of capitalism (Hay 1999), even if the ways in which this is done are spatio-temporally contingent. Here the notion of capitalist value relations exerting a 'gravitational pull' on social change is instructive because while allowing for a world of variety, it emphasises the tendency of states to reproduce property rights, access to natural resources and often provide the necessary conditions of social reproduction.

We do not seek here to submerge our propositions in the realm of state theory, but we do argue that the state is constitutive of commodity chains (and vice versa). The approach parallels Smith's outline of the 'constitutive role of state action at various scales in the establishment and restructuring of production networks' (2015: 291). Our central proposition here on 'seeing' the state in natural resource industries is to historicise its role in (re)producing commodity chains and lead firms within them (e.g. Glassman and Choi 2014). The articulations of state and capital take place in particular places and times and are thus always conjunctural (Pickles and Smith 2016). Whereas relations between capital, nature and states have been central throughout the history of capitalism, their concrete manifestations have changed in time and space. In other words, the relationship between the three has been historically structural but necessarily contingent. The tension between immanence and contingency - and the role of the state in it - provides fertile analytical ground to understand natural resource industries as GVCs.

In common with GVC analysis, while the state is often 'a background presence' in environmental economic geography, it 'has less frequently been the centre of attention' (Bridge 2014: 118). But as convincingly demonstrated by Bridge (2008), state hierarchies are particularly prevalent in natural resource industries precisely because capital 'touches down' so decisively (see proposition b). Investment in natural resource industries often takes place in regions otherwise excluded from concentrated accumulation, often in the 'global South', where territorial embeddedness deepens hierarchical and contested relations between resource-holding states and resource-seeking firms, and the geo-politics entailed therein. At the same time, if property is a bundle of rights implemented 
and conferred by social relations and reflected in juridical practices (MacPherson 1983), access to natural resources by firms is politically contingent upon historical time and geographical space (e.g. different players demand different conditions of access at different times).

States have played a historically enduring role in the making and remaking of commodity frontiers and commodity chains (e.g. Clarence-Smith and Topik 2003: Parenti 2015). These bear the stamp of the historical geography of imperialism and colonialism: that is, how imperial states set the rules of the game in international divisions of labour, old and new. Thus, considering states as a crucial piece of the puzzle goes beyond looking at 'interventions' in markets as states mean much more: 'they underpin and help to constitute [the] very existence [of markets]' (Dicken 2010: 179). As Hymer points out, largely in reference to FDI natural resource industries in the global South: 'In the last analysis, markets come out of the barrel of a gun, and to establish an integrated world economy on capitalist lines requires the international mobilisation of political power' (1972: 92).

As noted, the state-firm relationship is particularly salient and political in natural resource industries because of the materiality and concomitant territorial embeddedness of resources. As Parenti neatly puts it the environmental significance of the state as territory, [is] as the place of use values' (2015: 832, emphasis in original). Because the state is often 'resource owner' in extractive industries (e.g. in fishing and mining) or the body generating the institutional conditions of resource access (e.g. plantation concessions, 'land grabs'), state-firm relations at the point of extraction are a major site of struggle over the capture of surplus value in commodity chains. For example, the state's role as 'landlord'21 may enable it to appropriate rent from the process of resource extraction without being directly involved in production. The impacts of state-firm struggles over surplus value at the point of extraction have important effects on the value chain as a whole, and have been explored in oil drilling, platinum mining and tuna fishing (Bridge and Le Billon 2012; Campling and Havice 2014; Capps 2012, 2016; Coronil

\footnotetext{
${ }^{21}$ Here we are thinking through the prism of Marx's 'third class' of modern landed property (Neocosmos 1986).
} 
1997; Vitalis 2009). Firm strategies are developed in relation to these socioecological relations and processes, in turn having profound influence over issues such as price and supply in the value chain.

Overall, the state's relevance in natural resource industries looms large. Capitalist production requires and nurtures differential 'functions and capacities' of states which articulate contingently with firms along commodity chains. Again, with a view to better understand natural resource industries as GVCs, we suggest a series of questions. How do states support or hamper the appropriation of nature? Put more specifically in relation to proposition a, what is the role of states in general and of (historical) imperialism in particular in the bringing into being and widening of commodity frontiers? How and with what tools do states capture wealth from the territorial embeddedness of natural resources? For whom? How does the state shape circuits of capital and inter-firm relations in natural resource industries? Does state-landed property over natural resource industries shape GVCs? What conditions are necessary for state-landed property to shape natural resource value chains? And what does this mean for GVC theories of chain governance?

\section{Conclusions}

As Gavin Bridge points out "we live in a material world in which "the economy" is fundamentally (although not exclusively) a process of material transformation through which natural resources are converted into a vast array of commodities and by-product wastes' (2009: 1218). This article has sought to bring forward this 'material world' by suggesting an applied research agenda for the study of natural resource industries as global value chains.

We pursued a GVC analysis that is particularly sensitive to production. As such we frame GVCs through the analytical prism of the circuit of capital both at the firm and the commodity chain level, emphasising that relations of production and exchange are mutually constitutive. A GVC analysis that links relationally production within firms to exchanges between them furthers our understanding of globally dispersed forms of industrial organisation in general, and of natural 
resources in particular. To start accounting for this difference we devised five analytical propositions from which we developed a series of analytical questions. Commodity frontier theory shows us that capitalist production has always and will continue to work through the appropriation of nature, and is constantly moving in time and place. Therefore, while GVC analyses typically provide nuanced snapshots of the power relations that articulate activities in commodity chains, commodity frontier theory sets these snapshots in historical motion, capturing the dynamic transformations of capitalist production.

Our propositions are explicitly sensitive to history and contingency. At the same time, we have prioritised certain tendencies as analytical bases in our political economy of natural resources. To avoid pluralistic explanations ('chaotic wholes'), we limited ourselves to only five interlocking propositions, united by an overarching theoretical framework that highlights the circuits of capital and the commodity in capitalist production. In other words, our approach recognises the gravitational pull of the capital-relation but without prefiguring particular phenomenal forms and outcomes. For example, tendencies specific to natural resource industries such as the dual problematic of distance and durability cannot be explained by reference to capitalist circuits alone, but they do provide an initial explanatory 'way in' to explaining why (and how) the problems of distance and durability are overcome. In this way, our theorisation of capitalist production allows us to connect the five propositions: we see them working in a complex totality - none can be simply 'added on' to the existing GVC framework for example. Conversely, while both exploitation in the labour process and labour control regimes in natural resource industries may each seem generally similar to other industries, they are shaped intimately by the materiality of nature and in turn shape (and are shaped by) big capital in GVCs. Uncovering this crucial silence in both GVC analysis and labour process theory is a major contribution of this article, highlighting the validity of our approach and the associated need to move beyond the narrow silos that increasingly define much GVC research.

Ultimately, our propositions for a political economy of natural resources have an inherent political logic. While demand for particular natural resources changes, together with their manifold uses and transformations, and the technologies appropriating and transforming them, capitalism's general 
dependence on them remains. The materiality and material-intensity of capitalist production must be de-fetishized. Ultimately, this requires thinking beyond the obvious fact that capitalism causes problems for the environment, to contemplate more seriously the possibility that capitalism is the problem of the environment, and that struggles against the exploitation of labour and the untrammelled appropriation of nature must have common ground in their opposition to the brutalities of the capital-relation.

\section{References}

Adam, B, 1998, Timescapes of Modernity (Routledge)

Bair, J, 2009 "Global Commodity Chains", in Frontiers of Commodity Chain Research, Ed. J. Bair (Stanford University Press)

Bair J, Werner M, 2011, “The place of disarticulations" Environment and Planning A 43 998-1015

Bakker, K., 2012. "The matter of nature in economic geography", in The Wiley Blackwell Companion to Economic Geography Eds. T. Barnes et al. (Wiley Blackwell) pp. 104-117.

Bakker, K, Bridge, G, 2006, “Material worlds” Progress in Human Geography 30: 527

Benton, T, 1989 “Marxism and natural limits” New Left Review I 178: 51-86.

Bernstein, H, 2010, "Some Questions Concerning the Productive Forces" Journal of Agrarian Change 10 (3): 300-14

Bernstein, H, Campling, L, 2006, "Commodity Studies and Commodity Fetishism I" Journal of Agrarian Change, 6 (2): 239-64

Bezuidenhout, A, Buhlungu, S, 2011 "From Compounded to Fragmented Labour" Antipode 434(2): 237-263

Birch K, Tyfield D, 2013, "Theorizing the bioeconomy" Science, Technology \& Human Values 38(3), 299-327

Boyd, W, Prudham S and Schurman RA, 2001, "Industrial Dynamics and the Problem of Nature" Society and Natural Resources 14 (7): 555-570 
Boys, W. and Prudham, S. 2017, On the Themed Collection, "The Formal and Real Subsumption of Nature", Society and Natural Resources, 30 (7): 877-884

Bridge, G, 2000. "The social regulation of resource access and environmental impact" Geoforum 31 (2): 237-256.

Bridge, G, 2002, “Grounding Globalization” Economic Geography, 78 (3): 361-386.

Bridge, G, 2008. "Global production networks and the extractive sector" Journal of Economic Geography 8 (3): 389-419.

Bridge, G, 2009, “Material Worlds” Geography Compass 3(3), 1217-1244

Bridge G, 2013 'Territory, now in 3D!' Political Geography 34 55-57

Bridge, G, 2014, "Resource geographies II" Progress in Human Geography 38(1): 118-130

Bridge, G, Jonas A, 2002, “Governing nature" Environment and Planning A 34(5): $759-766$

Bridge, G. and P. Le Billon 2012, Oil, Cambridge: Polity

Brighton Labour Process Group 1977, "The Capitalist Labour Process" Capital \& Class 1: 3- 22.

Bowker G, 1987, “A Well Ordered Reality: Aspects of the Development of Schlumberger, 1920-39", Social Studies of Science 17 (4): 611-655

Burawoy M, 1982, Manufacturing Consent (University of Chicago)

Campling L, 2012. "The tuna 'commodity frontier'” Journal of Agrarian Change 12(2-3), 252-78.

Campling L, Havice E, 2014, "The problem of property in industrial fisheries" Journal of Peasant Studies 41 (5), 707-727.

Campling L, Colas A, forthcoming, Capitalism and the Sea, London: Verso

Capps G, 2012. "Victim of its own success?” Review of African Political Economy, 39(131), 63-84

Capps G, 2016, “Tribal-Landed Property” Journal of Agrarian Change 16 (3): 452477.

Castree N, 2003, “Commodifying what nature?” Progress in Human Geography 27(3), 273-297.

Clapp J, Helleiner E, 2012, "International Political Economy and the Environment" International Affairs, 88 (3): 485-501. 
Coe NM, Dicken P, Hess M, 2008, “Global Production Networks: realizing the potential" Journal of Economic Geography 8(3): 271-295.

Clarence-Smith WG, Topik S, (eds.) 2003, The Global Coffee Economy (Cambridge University Press)

Coronil F, 1997, The Magical State (University of Chicago)

Cumbers, A, Nativel C, Routledge P, 2008, "Labour agency and union positionalities in global production networks" Journal of Economic Geography 8: 369-387

Dias JF, Guillotreau P, 2005, "Fish canning industries of France and Portugal" Economia Global e Gestão, X(2): 61-79.

Dicken P,. 2010, Global Shift (Sage)

Field G, 2004, Territories of Profit (Stanford University Press)

Fine B, 1994, 'Coal, Diamonds and Oil” Review of Political Economy 6(3): 279-302.

Fine B, Leopold E, 1993. The World of Consumption (Routledge)

Fischer S. 2016, "Labour regimes, embeddedness and Commodity Chains”. PhD Thesis, Queen Mary University of London

Freidberg S, 2001, "On the trail of the global green bean" Global Networks 1(4): 353-368

Friedmann H, 1992, “Distance and Durability” Third World Quarterly 13(2): 37183.

Fujinami N., 1987. 'Development of Japan's Tuna Fisheries'. In Tuna Issues and Perspectives in the Pacific Islands Region, Ed. D. Doulman (East-West Center)

Gellert, PK, 2003, "Renegotiating a Timber Commodity Chain" Sociological Forum, 18(1), 53-84

Gibbon, P, Bair, J, Ponte, S, 2008 “Governing Global Value Chains” Economy and Society $37(3), 315-338$

Gibbs, D, 2006, "Prospects for an environmental economic geography" Economic Geography 82 (2): 193-215.

Glassman, J, Choi, YJ, 2014, "The chaebol and the US military-industrial complex" Environment and Planning A 46 1160-1180

Gouldner, AW, 1964, Patterns of Industrial Bureaucracy (The Free Press) 
Hall S, 1980, "Race, articulation and societies structured in dominance" Sociological Theories (UNESCO)

Harvey, D., 1974, "Population, Resources, and the Ideology of Science" Economic Geography 50, 3: 256-277

Hay, C, 1999, 'Marxism and the State', in Marxism and Social Science, Eds. A. Gamble et al. (University of Illinois Press)

Havice, E., Campling, L, 2013, “Articulating upgrading” Environment and Planning A, 45(11): 2610-2627.

Havice, E, Campling, L, 2017, "Where Chain Governance and Environmental Governance Meet" Economic Geography, DOI: 10.1080/00130095.2017.1292848

Henderson, G,L, 1999, California and the Fictions of Capital (Oxford University Press)

Henderson, J, Dicken P, Hess M, Coe N, Yeung HWC, 2002, “Global production networks and the analysis of economic development" Review of International Political Economy 9(3): 436-464.

Hymer, S. 1972, "The Internationalization of Capital”, Journal of Economic Issues 6 (1): 91-111

Hudson, R, 2008, “Cultural political economy meets global production networks" Journal of Economic Geography 8 421-440.

Kaup, BZ, 2014, "Divergent paths of counter-neoliberalization" Environment and Planning A 46(8): 1836-1851.

Kloppenburg JR., 2004, First the Seed (University of Wisconsin Press)

Levy, D, Newell, P, 2002, "Business Strategy and International Environmental Governance" Global Environmental Politics 2 (4): 84-101.

Levy, D., Newell, P, 2005, The Business of Global Environmental Governance (MIT) MacPherson, CB, 1983, Property (University of Toronto Press)

Mann, SA, Dickinson, J, 1978, “Obstacles to the Development of Capitalist Agriculture" Journal of Peasant Studies 5 (4), 466-481.

Marley, BJ, 2015, “The coal crisis in Appalachia”, Journal of Agrarian Change, 16(2): 225-254

Marx, K, 1981. Capital, Volume 3 (Penguin)

Marx, K, 1992, Capital, Volume 1 (Penguin) 
Marx, K, 1993, Capital, Volume 2 (Penguin)

Marx, K, 2008, Critique of the Gotha Programme (Wildside Press)

Moore, JW, 2010a. "Amsterdam is Standing on Norway" Journal of Agrarian Change 10 (2): 188-227.

Moore, JW, 2010b, “The End of the Road?” Journal of Agrarian Change 10 (3): 389413.

Moore, JW, 2011, "Ecology, capital, and the nature of our times" Journal of WorldSystems Research 17(1): 108-147.

Moore JW, 2012, “Cheap Food \& Bad Money”. Review, 33 (2-3).

Moore JW, 2015, Capitalism in the Web of Life, (Verso)

Muszynski A, 1996, Cheap Wage Labour (McGill-Queen's University Press)

Neilson J, Pritchard B, Yeung HWC, 2014, "Global value chains and global production networks in the changing international political economy" Review of International Political Economy 21 (1): 1-8

Neocosmos, M, 1986. “Marx's Third Class” Journal of Peasant Studies 13 (3): 5-44. Nest M, 2011, Coltan, (Polity)

Newell P, Paterson M, 1998, “A climate for business" Review of International Political Economy 5 (4), 679-703.

Newell P, 2011, "The elephant in the room: capitalism and global environmental change" Global Environmental Change 21: 4-6.

Newell P, 2012, Globalization and the Environment (Polity)

Newsome K, 2010, "Work and employment in distribution and exchange" Industrial Relations Journal 41(3): 190-205

Newsome K, Taylor P, Bair J, Rainnie A, (eds.) 2015, Putting Labour in its Place (Basingstoke: Palgrave Macmillan)

Nolan P, Zhang J, Liu C, 2008, “The global business revolution" Cambridge Journal of Economics 32(1): 29-47

Palpacuer, F, 2008, "Bringing the social context back in" Economy and Society 37(3): 393-419

Parenti, C, 2015, 'The Environment Making State' Antipode 47 (4): 829-848

Peluso, NL, Watts M, (eds.) 2001, Violent Environments (Cornell University Press)

Podobnik B, 2003, Global Energy Shifts: Fostering Sustainability in a Turbulent Age, Philadelphia: Temple University Press 
Pickles, J, Smith A, 2016, Articulations of Capital (Wiley)

Ponte, S, Sturgeon T, 2014, "Explaining governance in global value chains" Review of International Political Economy 21 (1), 195-223.

Rainnie, A., Herod, A., McGrath-Champ, S., 2011, "Review and positions: global production networks and labour" Competition and Change 15(2): 155-169.

Ross, C, 2014, “The tin frontier", Environmental History, 19 (3): 454-479.

Rugman A, Girod S, 2003, "Retail Multinationals and Globalization: The Evidence is Regional” European Management Journal, 21(1): 24-37

Scott, JC, 1995, “State Simplifications" Journal of Political Philosophy 3(3), 191-233

Selywn B, 2007, “Labour Process and Workers' Bargaining Power in Export Grape Production, North East Brazil" Journal of Agrarian Change 7(4): 526-553

Selywn B, 2012, "Beyond firm-centrism" Journal of Economic Geography, 12(1): 205-226.

Shaikh A, 2016, Capitalism (Oxford: Oxford University Press)

Shephard S, 2000, Pickled, Potted and Canned (London: Simon \& Schuster)

Smith A, 2015, "The state, institutional frameworks and the dynamics of capital in global production networks" Progress in Human Geography 39(3): 290315

Smith A, Rainnie A, Dunford M, Hardy J, Hudson R, Sadler D, 2002, "Networks of value, commodities and regions" Progress in Human Geography 26(1): 4163.

Smith C, 2006, The Double Indeterminacy of Labour Power', Work, Employment and Society, 20(2): 389-402.

Smith DA, 2005, "Starting at the Beginning", in Nature, Raw Materials, and Political Economy, Eds. P.S. Ciccantell et al, (Emerald), pp. 141 - 157

Smith N, 1996, "The production of nature", in FutureNatural. Nature, Science, Culture, Eds. G. Robertson et al. (Routledge)

Smith N, 2010, Uneven Development (Verso)

Starosta G, 2010, "Global Commodity Chains and the Marxian Law of Value", Antipode, 42(2): 433-465.

Taylor M., 2008, "Power, Conflict and the Production of the Global Economy", in, Global Economy Contested Ed. M. Taylor (Routledge)

UNCTAD 2013, Global Value Chains and Development, Geneva: UNCTAD 
Vitalis R, 2009, America's Kingdom: Mythmaking in the Saudi Oil Frontier (Verso)

Walker R.A., 2001, “California's Golden Road to Riches: Natural Resources and Regional Capitalism, 1848-1940" Annals of the Association of American Geographers 91 (1): 167-199.

Walker R, Thomas S, 2010, "Blinded by history: The geographic dimension of environment and society", in A Companion to American Environmental History Ed. D.C. Sackman (Wiley-Blackwell)

Warne D, 1988, "Manual on Fish Canning" FAO Fisheries Technical Paper 285, Rome: FAO.

Weis T, 2007, The Global Food Economy (Zed)

Yeung HWC, Coe N, 2015, "Toward a Dynamic Theory of Global Production Networks" Economic Geography 91 (1): 29-58

Zalik A, 2015, 'Trading on the Offshore: Teritorialization and the Ocean Grab in the International Seabed', in Kate Ervine and Gavin Fridell (eds.) Beyond Free Trade: Alternative Approaches to Trade, Politics and Power, London: Palgrave.

Zimmerman, E. W. (1951), World Resources and Industries: A Functional Appraisal of the Availability of Agricultural and Industrial Materials, New York: Harper 